【総説】

健康食品の見分け方

一その情報の問題と対処法一

\section{How to Choose Best Dietary Supplement}

- The Issues of Information on Dietary Supplements in Japan-

\section{小内 亨 \\ Toru ONAI}

おない内科クリニック

\section{【要 旨】}

日本で入手できる健康食品に関する情報のほとんどは 広告である. 広告から得られる情報にはバイアスがか かっており，そこから健康食品の科学的評価やその問 題に関する情報を得ることはできない. 日本の健康食 品には臨床研究が不足しており, 不均一性, 副作用, 医薬品との相互作用など様々な問題がある。したがっ て，自分に適した健康食品を選択するためには，広告 情報の限界を知り，そこから得られない情報について 積極的に収集する姿勢が重要である.

【キーワード】

健康食品, サプリメント, ハーブ, ビタミン, ミネラル

\section{1. 健康食品の定義と位置づけ}

一健康食品には定義がない一

一般に健康食品は食品と医薬品との中間的なものと捉 えられているが，法律上は食品である。その他，サプリ メント，栄養補助食品，健康機能食品など様々な呼称が 用いられているが，それぞれの区別はない。米国栄養補 助食品健康・教育法 (Dietary Supplement Health and Education Act of 1994, DSHEA) では Dietary Supplement （栄養補助食品）を「錠剤，カプセル等の医薬品のような 形状の食品であって，ビタミン，ミネラル，アミノ酸， 生薬等の植物由来成分等を摂取するもの」と定義してい る。米国と異なり，日本では健康食品の明確な定義がな いため，人により健康食品の意味するところが異なる. ビタミン・ミネラルのみを健康食品とみなす人もいれば, ハーブ類などの植物成分やキトサンなどの動物成分など さまざまな成分をも健康食品に含める人もいる．日常の 食事さえしっかりしていれば，健康食品など不必要であ るといら意見は，ハーブ類などを健康食品に含めている 人にとっては全く見当違いのものとなってしまら.

本稿では, 上記のよらな議論の食い違いをさけるため, 「保健上の効果を期待して一般の食事とは別に摂取する 食品」と暫定的に定義し，論を進めたい1)。このように 目的と摂取方法から健康食品を定義した場合，表 1 に示 した如く，日本では様々な健康食品が流通している。さ らに年々その種類は増加している。 これらの健康食品を まとめて取り上げ，論ずるには無理があるが，あえてこ こでは総論的に取り上げてみたい，この方が，かえって 日本に打ける健康食品の問題が読者に拈わかりいただけ るのではないかと考えているからである。

表 1 日本で流通している健康食品の種類とその例

ビタミン: ビタミン $\mathrm{A}, \mathrm{E}, \mathrm{D}$, ビタミン $\mathrm{B}$ 群
ミネラル : カルシウム, マグネシウム
アミノ酸 : L-カルニチン
タンパク質, ペプチド : プロテイン, 大豆ペプチド
脂肪酸 : DHA, EPA
糖質 : オリゴ糖
食物緘維 : 難消化デキストラン, サイリウム
動物成分 : キトサン, コンドロイチン, プロポリス
植物成分 : ハーブ類, 樹皮成分, きのこ
注）米国でdietary supplementとして流通しているメラトニンな
どは日本では医薬品


表 2 保健機能食品といわゆる健康食品の表示

\begin{tabular}{|c|c|c|c|}
\hline \multirow[b]{2}{*}{$\begin{array}{c}\text { 医薬品 } \\
\text { 医薬部外品 }\end{array}$} & \multicolumn{2}{|c|}{ 保健機能食品 } & \multirow[b]{2}{*}{$\begin{array}{c}\text { 食品一般 } \\
\text { いわゆる健康食品 }\end{array}$} \\
\hline & $\begin{array}{c}\text { 特定保健用食品 } \\
\text { (個別許可型) }\end{array}$ & $\begin{array}{l}\text { 栄養機能食品 } \\
\text { (規格基準型) }\end{array}$ & \\
\hline 効能・効果の表示など & $\begin{array}{l}\text { 栄養成分含有表示 } \\
\text { 栄養成分機能表示 } \\
\text { 注意喚起表示 } \\
\text { 保健用途の表示 }\end{array}$ & $\begin{array}{l}\text { 栄養成分含有表示 } \\
\text { 栄養成分機能表示 } \\
\text { 注意喚起表示 }\end{array}$ & 栄養成分含有表示 \\
\hline
\end{tabular}

文献 16)より（一部改変）

人の口に入るものは法律上は医薬品か食品しかない. その区別は厚生労働省により決められている. この区別, つまり食薬区分は定期的に見直され，随時変更されてい る. 医薬品に区分されれば薬事法の制約のもとその流通 は制限されるが，食品に分類されれば健康食品としての 流通が可能となる.つまり，食品に分類されることでそ の市場は飛躍的に広がる可能性がある。その典型が平成 13 年に医薬品から食品に区分変更されたコエンザイム Q10である. 医薬品であったときには一般消費者に知ら れることの無かったものが，今では誰もが自由に購入す ることができるよらになり一気に市場が広がった。した がって，食薬区分には様々な利害関係が絡み，市場開放 といら意味から海外の圧力もかかっている．海外で健康 食品として流通しているものの中には日本では医薬品と みなされているものもあるため, 海外の健康食品業界に とって薬事法が一つの輸入障壁となっている．当該成分 が医薬品から食品へと区分変更されれば，この障壁が取 り除かれたことになる. 近年, 食薬区分の見直しに伴い, ビタミン，ミネラル，八ーブ類は次々と食品とみなされ るよらになり，これらを原料とした健康食品が日本でも 流通するようになった。これは，厚生労働省が規制緩和 推進計画や市場開放問題苦情処理推進会議 (OTO) に対 応してきた結果である. 平成 14 年に L-カルニチンが医 薬品から食品に変更されたが，これはスイス大使館から の苦情申し立てがきっかけとなった ${ }^{2)}$. 食薬区分の見直 しの経緯をみると，健康食品の規制緩和の流れは，業界 や海外からの圧力のもとに行われたものであって, 決し て消費者の健康を考えた上ではないことが分かる.

やはりこの規制緩和の流れの中で，保健機能食品制度 が創設された。保健機能食品は栄養機能食品と特定保健 用食品とに分けられる（表 2 ）。それぞれ一部保健上の用 途を表示することが認められ，その他の健康食品と区別 されるよらになった。 これにより一部のビタミン，ミネ ラルは栄養機能食品としてその地位を確立し，科学的根 拠の明らかなものは特定保健用食品の表示を許可される ようになった。しかし， 汪とんどの健康食品はこれらの
範疇からはずれたため，以下に述べるような様々な問題 を引き起こし，その結果その選択を難しくしている．本 稿では保健機能食品を区別せず論ずることとする。

\section{2. 健康食品に関する情報の問題点 一ほとんどの情報は広告一}

ある調査によれば，一般の人が入手する健康食品の情 報源のほとんどが，テレビ，雑誌をはじめとしたマスメ ディア，広告，インターネットやロコミであるという． これらの情報の大部分は広告である，消費者は，医師や 薬剂師などの医療の専門家から情報を得ることなく，広 告からの情報を頼りに健康食品を選択しているのであ る。当たり前のことだが，広告では健康食品のよい面し か伝えず，科学的評価などの客観的情報や副作用などの 販売者側にとって都合の悪い面を伝えることは少ない， 医薬品であれば，販売者が利用者に副作用や他の医薬品 との相互作用などの情報を提供する義務があるが，健康 食品販売者にはそのような義務はない，消費者は極めて 偏った情報に基づいて健康食品を選択せざるを得ず，こ のことが健康食品への過大な期待を抱く要因ともなって いる.

一般の食品ならばこのよらな情報の偏りはそれほど問 題とはならないが，健康食品では重大な問題である。一 般の食品であれば一度食べてまずければその後二度と購 入しなければよい。このように人の通常の感覚で判断, 選択が可能である。 これに対し，健康食品の場合，その 目的である「健康によい」ということを自らの感覚で判 定することは難しい. つまり，何の情報もなしに試用し て判断することは不可能である。 しかも，半永久的に摂 取しなければ効果が得られないとなればな拈さらであ る. 5 年たったら結局無意味であることが分かった，と いらのではすでに手遅れだ。

したがって，健康食品を利用するかしないか，何を利 用するかなどを判断するためには，正確で客観的な情報 が必須となる。 その点，広告は情報源としては極めて不 
十分である. 広告に惑わされないようにするためには, 広告で使用されるテクニックを知ること，広告に現れな い情報を積極的に収集することが肝要となる。

\section{3. 広告で使用されるテクニック 一広告に惑わされないために一}

本来健康食品は食品であるので, 医薬品のように効能・ 効果を広告することはできない，このため，健康食品の 広告では様々な方法を使って間接的に効能・効果を伝兄 ようとする。 それが科学的根拠に基ついたものであれば 問題ないが，そのほとんどに科学的根拠があるとはいえ ない。

\section{1 権威の利用}

しばしば健康食品の広告には医学博士を名乗る人の推 薦の言葉が掲載されている，時にそれは実際の医師で あったりする，専門家の言葉に対して，しばしば素人は 思考を停止してしま ${ }^{3)}$. 悪質な例として本人の了解を 得ずに勝手に推萀文を載せていた例もある4)。また，乙 ばしば健康食品を販売する会社の名称が「○○研究所」 となっていたり, タレントの起用, 賞を受賞したとかオ リンピック選手が採用したとか，様々な方法で権威を利 用しょらとする.

\section{2 詳細な解説}

健康食品の解説の中には, 病気の成り立ちやなぜその 健康食品が効くのかといった解説を載せている場合があ る。そこではしばしば難解な医学用語やもっともらしい イラストなどが使われているが，これらは皆，科学的な 雾囲気を演出するための小道具であり, 権威を利用した 方法の一つである。 その内容を詳細に検討してみると断 片的な医学情報を頼りに創作されたものであり，医学的 に誤りも多い。このような広告方法は薬事法違反となる 可能性がある.

\section{3 脅かしと救済}

健康食品の効果を強調するため, ことさら疾病の恐ろ しさを強調する方法がある。場合によっては，一般医療 に対する批判とともに揭載されていることもある。 たと えば,「糖尿病に対してインスリンを注射すると体の中の インスリンをつくる働きが衰光，合併症が進み目が見光 なくなります.」といった具合である. その説明の後に, 健康食品の効果と安全性を訴兄，そ恎により救済できる と主張する.「この健康食品なら自然治癒力を高め徐々に 病気を改善していきます。といった表現が使用される。
これは人の心理を巧みについた広告方法の一つであ $ろ^{5)}$.

\section{4 体験談の利用}

健康食品利用者の疾病が改善したという声を掲載する ことにより間接的にその商品の効果を訴える方法もよく 利用される。 このような情報は，医学的に全く不正確で あり，作り話である可能性も否定できない，実際にダイ エット用健康食品の広告に利用されていた体験談が社員 によりねつ造されたものであることが明らかになった例 もある. ダイエット前後の写真などもコンピュータグラ フィクスを利用すれば容易に作成することができる。 し かし, 体験談を載せる方法は, 読者が身近に感じること, 色々な疾病を載せることができること，真実味を持たせ ることができることなどの理由により，有効な広告方法 である.

\section{5 返報性の法則の利用}

人は他人によくしてもららとそれに報いようとする. これを返報性の法則と呼ぶ3. 無料で試用品や解説の小 冊子を送ってもらったり, 無料相談を受けたりすると, ぞうしてもその健康食品を購入せざるを得ない心理状態 になってしまう。まさに「ただより高いものはない.」と いうことである.

\section{6 バイブル本商法}

しばしば新聞の広告欄に「がんが治った」などという タイトルの書籍の広告がある。これはバイブル本商法と 呼ばれる広告・販売方法である，直接的に健康食品の効 能・効果を広告することができないため，その内容を書 籍の形として消費者に知らしめる方法である。書籍の中 での記述は表現の自由として許される。特定の健康食品 の効果をたたえるその内容はまさに上記の $3.1 〜 3.5$ の方 法を駆使したものとなる。 しか子健康食品の有効性を訴 えるタイトルを本に冠することで，書籍の広告が健康食 品の広告をも兼抆ることになる。書籍の広告を有名新聞 に掲載することにより，新聞の権威も利用できる，書籍 の形体は折り込みチラシなどに比べて信憑性が高いと思 われがちであることも都合がよい，巻末に連絡先を記し ておけげ，読者から直接注文を受けることができるし， 販売者がその書籍を用いて宣伝することもできる。

\section{4. ロコミ情報の弊害一古くて新しい問題一}

今も昔も口コミは重要な情報の伝達手段である。健康 食品に限っていえばロコミは以前にも増して影響力の強 
い情報源となりつつある。携帯電話やインターネットの 普及とともにロコミは今までになく効率よく広がるよう になってきた，健康食品の販売，広告方法もそれに応じ て変化してきている.インターネットの匿名性を利用し， 販売者が患者になりすまして特定の健康食品の効果を宣 伝することも可能である6)。 また，患者さんのもとには ぞこからともなく，健康食品を勧める知人が現れ，自ら の体験や伝兄聞いた体験を話し, 特定の健康食品の購入 を勧める．ときにその知人自身が健康食品の販売者であ ることもある，人間関係を壞したくないために，嫌々な がら健康食品を購入する例もあり，今後社会問題化する ことも考兄られる.

\section{5. マスメディアの関与一スポンサーの影一}

健康食品産業の隆盛とともに，しばしば健康食品のテ レビコマーシャルを目にするようになった。一般の健康 に対する関心の高まりとともに健康情報番組は隆盛を極 めている.テレビはもっとも影響力の強いメディアでは あるが，その提供する情報が常に正確で客観性を持って いるかは疑問である. 民放には必ずスポンサーが存在し, テレビの提供する情報はスポンサーの影響下にある。す なわち，健康食品企業がテレビの強力なスポンサーとな れば，企業にとって都合の悪い情報，つまり健康食品の 科学的根拠やそれによる副作用などの問題は噯蔽される ことになる. 新聞や雑誌なども同様の問題を有している. したがって，マスメディアからの情報であるからといっ て，無条件に信用するわけにはいかない。

\section{6. 広告情報で隠れていること一エビデンスとリスクー}

日本で流通している健康食品には様々な問題がある。 ところが，その詳細を広告からはらかがい知ることはで きない，乙かも，上記の理由によりマスメディアも健康 食品の問題を取り上げることは少ない，あらかじめ健康 食品にはどのような問題があるのかを把握し，積極的に 自分で探さない限り，正確な情報を得ることができない のである．健康食品のマイナス面を知らずに健康食品を 利用すると，健康になるどころかかえって健康を害した り，不要な出費を強いられたりする可能性がある。ここ では筆者の考光る次のよらな健康食品の問題点をあげて 扣きたい。

1）健康食品のエビデンス（科学的根拠）の問題

2）健康食品の質の問題

3）健康食品による健康障害の可能性（過㮃症, 副作用,
不純物，医薬品との相互作用，疾病への影響，医療 への影響)

1）健康食品のエビデンスは一般に考兄られているほど 多くない

私は患者さんの質問に答えるため，しばしば健康食品 のエビデンスを探すことがあるが，実際には健康食品は 広告で宣伝されているような効果が科学的に証明されて いないことが皃とんどである。たとえあったとしても細 胞実験や動物実験で効果が示されただけのものが多い， ある意味ではこれらも科学的根拠といえるかもしれない が，EBM（科学的根拠に基ついた医療）の考方方からす れば，人を対象とした研究でない限りまったく参考とは ならない。

健康食品に効果があることを科学的に証明するために は人を対象とした比較試験が必須である。できればラン ダム化比較試験が望ましい，ところが，ほとんどの日本 の健康食品では比較試験が行われていないのが現状であ る．健康食品は医薬品でないから対照試験は必要ないと いら意見もあるが，筆者は以下の理由により健康食品に も臨床研究が必要であると考える。

a) 基礎研究や疫学的研究にて特定の成分の有効性が示唆 されていても，その成分による臨床研究にて直接的に 証明されなければ，七トに本当に有効であるかどらか は分からない，たとえば，及カロチンの効果をメタア ナリシスにより検討した論文によれば，予測に反して 祅ロチンを服用した人達で死亡率が増加したとい $5^{7}$.

b）たと六効果があったとされても，その効果の大きさが 人の健康に対して意味のある変化をもたらさなければ その重要性は乏しい，たとえば，ある健康食品にコレ ステロール低下作用があったとしよう。しかし，これ がコレステロールをわずか 3\%しか低下させることが できなければ，臨床的に有用であるとはいえない，こ のように，臨床研究によりその効果が定量的に測られ なければ臨床的有用性を評価できない場合もある。

c) 複数の健康食品の中から自分にふさわしいものを選択 するためには，共通の指標つまり臨床研究がなければ ならない。

d）経験のみに頼った判断が必ずしも正しいとは限らな い，たとえそれが医師であっても当てはまる。たと光 ば，過去に使用した健康食品で病気が改善した例を経 験するとそれが強く印象に残り，その健康食品の有効 性を過大評価してしまうことがある。このような判断 過程の問題をヒューリスティックと呼ぶ．経験は重要 であるが，より正確な判断のためには臨床研究などの 客観的なデータにより経験の偏りを修正することも必 
要なのである.

e）有害性の頻度・重症度が明らかでないと, 有効性との 比較に挍いて，個人に有用であるか判断できない，

f）健康食品の有効性が示される用量, 使用期間は臨床研 究によって初めて明らかとなる。 それに基づいて健康 食品にかかる費用が推測できる，健康食品にかかる費 用によって，健康食品を利用するかどらか判断が变 わってくる場合もあるのである.

このように健康食品のエビデンスはその利用の判断, 選択の際に重要な情報でありながら，日本のほとんどの 商品にはエビデンスがないそ理由はいろいろ考えら れる. まず第一に健康食品企業側に臨床研究を行らイン センティブが働かないといらことがあげられる。たとえ その健康食品にエビデンスがあってもそれを広告するこ とはできない。つまり，エビデンスの有無を商品の差別 化に利用することができなければ，企業側にメリットは 出ないのである。 それどころか臨床研究に投資した分, 商品コストが高くなってしまう。臨床研究には手間と時 間，多大な費用がかかるからだ。医薬品であれば，その 効果が証明されない限り市場に出ることはないが，健康 食品の場合はエビデンスの有無にかかわらずすでに市場 に出ている. かえって, 臨床研究の結果, その効果が否 定されれば商品にとっては大きなマイナスとなってしま う。以上を考えれば，企業にとって臨床研究などより宣 伝広告に投資した方が企業の収益が上がるであろう。

もら一つは，なかなか臨床研究への医師や医療機関の 協力が得られないといら問題がある. 多くの医師は健康 食品の効果に懐疑的であること, 健康食品では医薬品ほ ぞの効果を得ることが難しいこと，まだ健康食品は医薬
品と比べて業績として低くみられていること，などがそ の要因として考えられる.

以上の問題が解決されない限り，なかなか健康食品の エビデンスは生まれてこないであろう。

2）健康食品ごとに質が異なる

健康食品には定義がない以上，食品あるいは食品添加 物としての規制しかない，そのため商品名が必ずしもそ の内容を保証しない.「健康食品 ○○茸」といら商品に必 ずしも ○○茸が入っているとは限らないし，成分を チェックするシステムがないので判別も不可能である. 私たちはパッケージの表示を信じるしかないのである.

実際に国民生活センターが市販されているイチョウ葉 食品の成分を調べたことがある。その有効成分であるフ ラボノイド，テルペノイドが十分量含まれている商品も あればまったく含まれないものもあった（図 1 )。ドイッ ではイチョウ葉エキスが医薬品として認められているた め，その有効成分に関し含有量の基準がある。 それに比 ベ日本ではその基準がないため，同じ名称でも商品によ り効果が異なってしまらのである。このような問題は日 本のどの健康食品にも起こりえる. 日本製のセント・ジョ ンズ・ワートと呼ばれるハーブを用いた健康食品の有効 成分を調べた研究でも，日本の製品の中にはその有効成 分であるヒペルフォリン, ヒペリシンが海外製品の 10 分 の 1 以下といら商品もあった ( $^{8}$ (図 2 ).

健康食品の成分が一定しない要因はいくつかある. ハーブを原料にした健康食品の場合は，その採取時期， 葉，茎，根などの採取部位，栽培地域，抽出方法などに よりその成分構成が異なる可能性がある。しかも，八一 ブ類はその有効成分が単一でなかったり，まだ分析され
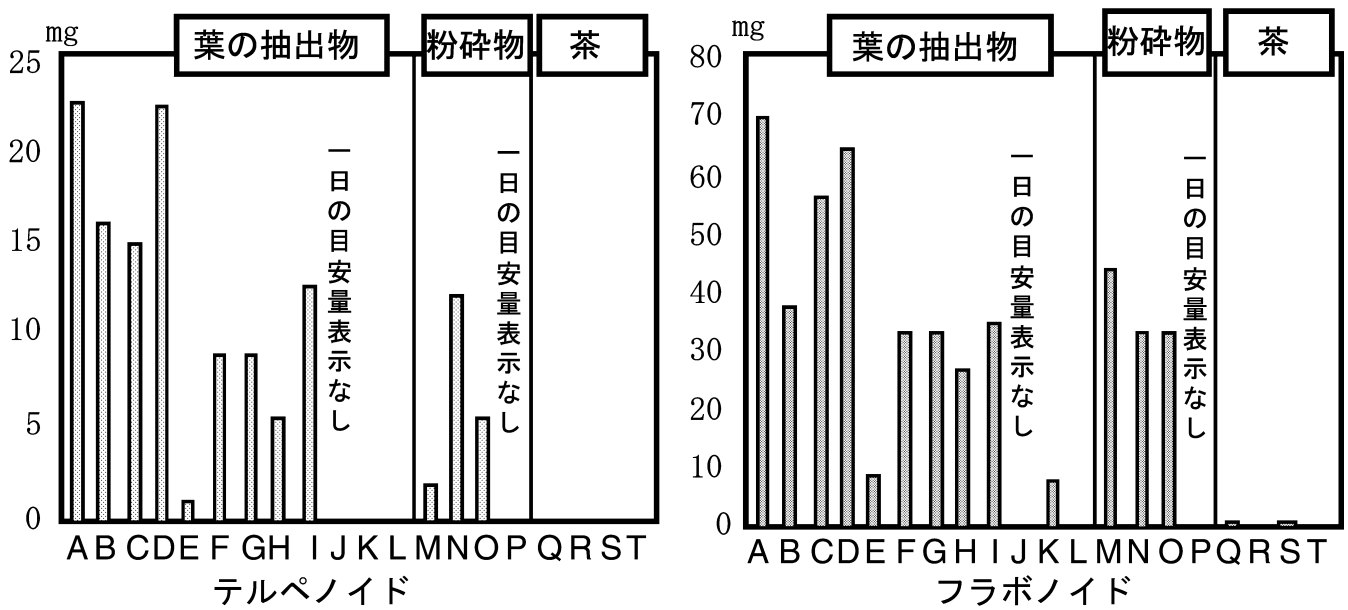

図 1 日本製イチョウ葉食品 $(\mathrm{A} \sim \mathrm{T})$ の成分比較

国民生活センター，記者説明会資料，「イチョウ葉食品の安全性（概要）〜アレルギー物質とその有効成分について考える〜」より引 用, 一部改変 


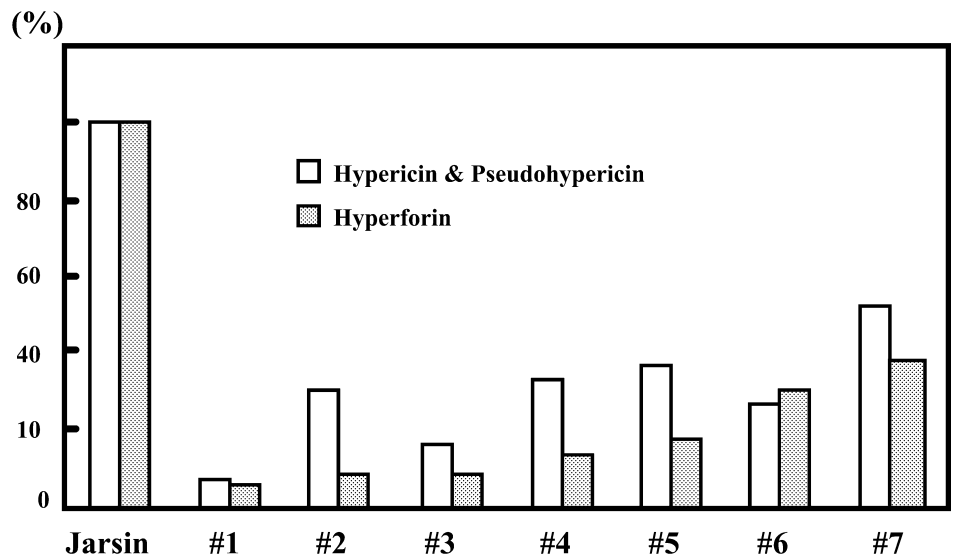

図 2 セント・ジョンズ・ワートの成分比較

セント・ジョンズ・ワート含有健康食品などから 1 日あたりに摂取される Hypericin 類および Hyperforin 量の目安（海外製品 Jarsin 300 に対する割合）

文献 8)より

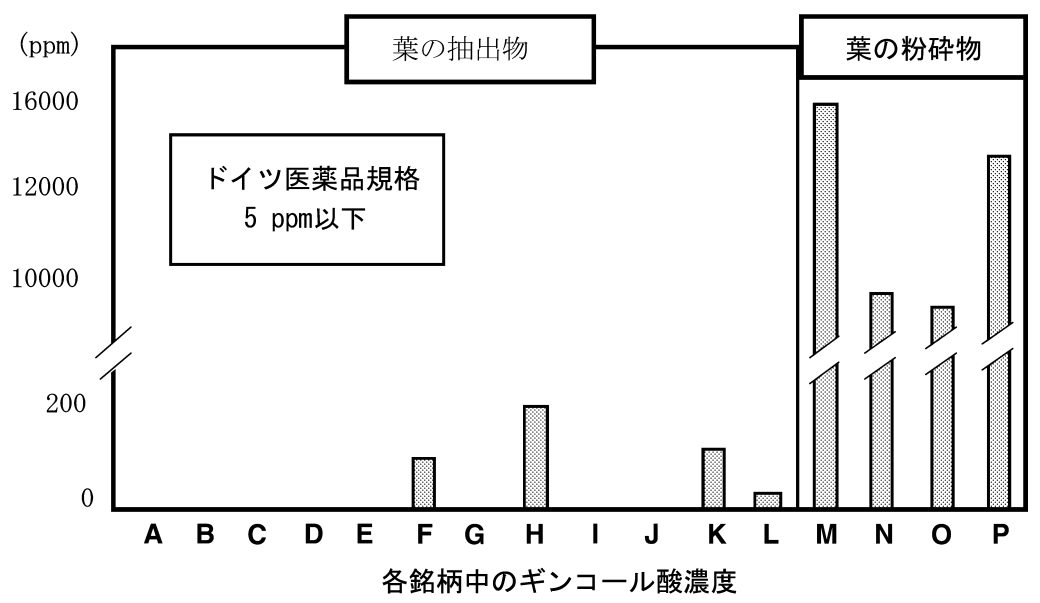

図 3 日本製イチョウ葉食品 $(\mathrm{A} \sim \mathrm{P})$ に含まれるギンコール酸

国民生活センター，記者説明会資料，「イチョウ葉食品の安全性（概要）〜アレルギー物質とその有効成分について考える〜」より引 用, 一部改変

ていなかったりするため規格の統一が難しい。蜜蝋とも 呼ばれるプロポリスの成分は百数十種類以上同定されて いる. しかも，その成分は産地によって異なる. ぞの成 分がどのように働いているのか，どのように相乗作用が 働いているのかなど未知の部分が多いため，これらの成 分を統一することはきわめて困難である.

3）健康食品による健康障害

従来健康食品は食品であるので安全であると一般に考 えられていたが，よく調べてみる様々な問題があること がわかる．健康食品の中には肝障害をはじめとした様々 な副作用が報告されている。今までもアガリクス茸によ

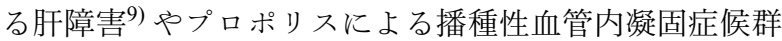
(DIC) を伴った肝障害例 ${ }^{10)}$ が報告されている．健康食品
といっても必ずしも安全とはいえないのである.

国民生活センターは市販されているイチョウ葉食品の アレルギー反応など有害作用をきたす成分であるギン コール酸の含量を調べた。 ドイッの基準ではこの副作用 の原因物質は $5 \mathrm{ppm}$ 以下となっている。 ところが，日本 の製品の中には, $10000 \mathrm{ppm}$ 以上とこれをはるかに上回 る量含まれている商品もあることが判明した（図３）。日 本では他の健康食品についても安全基準はなく，常に健 康障害の危険性をはらんでいる.

また，ある程度安全性が証明されていたとしても，力 プセル型や錠剤などでは常に過剰摂取の危険性がある.

より多く摂取すればより効果が得られるだろらといった 安易な考えにより過唾摂取し，過唾症の問題が起こる可 
表 3 ダイエット用健康食品による健康障害

\begin{tabular}{|c|c|c|c|c|c|c|}
\hline & 原因成分 & 生産国 & 被害発生国 & 健康障害 & 被害者数 & 時 期 \\
\hline ダイエット茶 & センナ & 日本, 海外 & 日本 & 不明 & 不明 & 1990 年代 \\
\hline ダイエット茶 & フェンフルラミン & 中国 & 日本 & 不明 & 不明 & 1990 年代 \\
\hline ダイエット茶 & 麻黄 & 海外（不明） & 日本 & 不明 & 不明 & 1990 年代 \\
\hline ダイエット茶 & ウワウルシ & 海外（不明） & 日本 & 不明 & 不明 & 1990 年代 \\
\hline ダイエット茶 & ダイオウ & 海外（不明） & 日本 & 不明 & 不明 & 1990 年代 \\
\hline $\begin{array}{l}\text { ダイエット用漢方 } \\
\text { 薬 }\end{array}$ & アリストロキア酸 & 中国？ & $\begin{array}{l}\text { ベルギー, 英国, } \\
\text { フランス, 日本な } \\
\text { ど }\end{array}$ & $\begin{array}{l}\text { 腎障害, 腎不全, } \\
\text { 尿路系悪性腫瘍 }\end{array}$ & 100 人以上 & 1990 年代前半 \\
\hline ダイエットピル & $\begin{array}{l}\text { フェニルプロパ } \\
\text { ノールアミン }\end{array}$ & 米国 & 米国 & 出血性脳卒中 & $\begin{array}{l}\text { 出血性脳卒中の } \\
\text { オッズ比 ; } 15.92\end{array}$ & 1994 年 1999 年 \\
\hline ダイエットピル & エフェドラ & 米国 & 米国 & $\begin{array}{l}\text { 高血圧, 動悸, } \\
\text { 頻脈, 脳卒中, } \\
\text { 痤攣, その他 }\end{array}$ & $\begin{array}{l}\text { 死亡 } 10 \text { 人, 後遺 } \\
\text { 症の残った人 } 13 \\
\text { 人, 総計 } 98 \text { イベ } \\
\text { ント }\end{array}$ & 1997 年 1999 年 \\
\hline LipoKinetix & $\begin{array}{l}\text { ノルエフェドリン } \\
\text { など }\end{array}$ & 米国 & 米国 & 肝障害 & 7 人 & \\
\hline $\begin{array}{l}\text { ダイエット用漢方 } \\
\text { 薬 }\end{array}$ & フェンフルラミン & 中国 & 英国 & $\begin{array}{l}\text { 高血圧, 動悸, } \\
\text { 不安感 }\end{array}$ & 数人 & 2001 年 \\
\hline $\begin{array}{l}\text { 中国製ダイエット } \\
\text { 用健康食品 }\end{array}$ & $\begin{array}{l}\text { フェンフルラミ } \\
\text { ン, N-ニトロン } \\
\text { フェンフルラミン, } \\
\text { 甲状腺ホルモン }\end{array}$ & 中国 & $\begin{array}{l}\text { 日本, 中国, シン } \\
\text { ガポール, 韓国 }\end{array}$ & $\begin{array}{l}\text { 肝障害, 甲状腺機 } \\
\text { 能異常など }\end{array}$ & $\begin{array}{l}\text { 死亡（日本 } 4 \text { 人, } \\
\text { 中国 } 2 \text { 人, シンガ } \\
\text { ポール } 1 \text { 人), そ } \\
\text { の他被害者 } 600 \text { 人 } \\
\text { 以上 }\end{array}$ & 2001 年 $\sim 2002$ 年 \\
\hline
\end{tabular}

文献 17) より

能性も否定できない.

健康食品による健康障害の中には，過剩摂取やアレル ギー反応などその主成分が影響する場合もあれば，不純 物が混入したことによる問題もある. 特に, 平成 14 年に は中国製ダイエット用健康食品による死亡例があっ $た^{11)}$.これはN-ニトロソフェンフルラミンが混入してい たため，これが劇症肝炎を起こしたものであると考兄ら れているが，従来よりダイエット用健康食品では不純物 による問題が繰り返し起こっている．代表的な例を表 3 に示した. 特に中国など海外製品には注意が必要である.

従来健康食品は健常者が利用するものであった．乙か し，今は小児，妊婦，高齢者や患者までも健康食品を利 用している，そのために，健康食品を誰が利用するかに ついても考慮しなけ机ばならない，妊婦ではビタミン A の過剰拱取により催奇形性が高まるなどの問題がある. しか子，多くの健康食品では胎児や乳幼児，小児に対寸 る安全性が確立していない. したがって, 妊婦・授乳婦, 乳幼児，小児等では特定のビタミン・ミネラルを除いて 原則的に健康食品を利用すべきではないと考光る.

最近は疾病を持つ人達も健康食品を利用するように なってきている，その際に問題となるのが，健康食品の 疾病や医薬品の効果への影響である. 多くの健康食品で はそれに含まれる成分の代謝の詳細が分かって扮らず,
肝疾患や腎疾患を持つ患者, あるいは代謝能力の低下し ている高齢者などでは慎重に使用すべきである。

セント・ジョンズ・ワートが薬物代謝酵素を誘導し薬 剂の効果を減弱するといら報告がされてから ${ }^{12}$, 健康食 品と医薬品との相互作用に注目が集まってきている。 セ ント・ジョンズ・ワートが薬物代謝酵素チトクローム P450 の酵素誘導をすることで薬物濃度を低下させるこ とが明らかになっているが，その他の健康食品にも類似 の働きがある可能性もある．現在明らかになっている医 薬品との相互作用が疑われる健康食品を表 4 亿掲げた.

また，一部の健康食品では手術時に易出血性を示した り，麻酔の作用に影響を与えたりするものがあるため， 術前に中止して和かなければならないものもある。そ水 らを表 5 に示した。

\section{7. 健康食品を利用する目的 一目的により必要な情報が異なる一}

以上の問題を踏まえて健康食品を利用するかしないか を判断することになる。冒頭で健康食品を利用する目的 を「保健上の効果」と述べたが，それに対する考光方は 個々人で全く異なる。ここをはっきりさせておかないと， 全く議論が食い違ってしまう可能性がある。このため, 
表 4 医薬品との相互作用の疑われる健康食品

\begin{tabular}{|c|c|c|c|}
\hline 健康食品 & 医薬品 & 相互作用 & 備 \\
\hline \multirow[t]{2}{*}{ ビタミン A } & テトラサイクリン & $\begin{array}{l}\text { 薬剂誘起性頭蓋内圧光進（激しい頭痛） } \\
\text { を強めることがある. }\end{array}$ & \\
\hline & ワルファリン & $\begin{array}{l}\text { ワルファリンの作用を増強させる可能性 } \\
\text { がある. }\end{array}$ & \\
\hline ビタミン B6 & L-dopa & L-dopa の作用を減弱させる. & $\begin{array}{l}\text { ビタミン B6 は L-dopa 変換酵素活性を亢進す } \\
\text { る作用がある. }\end{array}$ \\
\hline 葉酸 & フェニトイン & フェニトイン濃度が低下する. & \\
\hline ビタミン C & $\begin{array}{l}\text { ジエチルスティルベストー } \\
\text { ル, エストロゲン }\end{array}$ & 血中エストロゲン濃度の上昇. & \\
\hline ビタミン D & ジゴキシン & ジゴキシン毒性が増す可能性がある. & 高カルシウム血症を介した作用. \\
\hline ビタミン K & ワルファリン & ワルファリンの効果を減弱する. & \\
\hline $\begin{array}{l}\text { 抗酸化物質 (ビタミン } \\
\text { E, ビタミン C, } \beta \text { カ } \\
\text { ロチン, セレニウム) }\end{array}$ & $\begin{array}{l}\text { シンバスタチン+ナイアシ } \\
\text { ン }\end{array}$ & $\begin{array}{l}\text { シンバスタチン+ナイアシンの冠動脈硬 } \\
\text { 化抑制作用を減弱するとの報告がある. }\end{array}$ & \\
\hline $\begin{array}{l}\text { カモミール, } \\
\text { Chamomile }\end{array}$ & ワルファリン & $\begin{array}{l}\text { ワルファリンと相互作用を示す可能性が } \\
\text { ある. }\end{array}$ & $\begin{array}{l}\text { カモミールはクマリンを含む. ただし, 臨床 } \\
\text { 的に問題になったことはない. }\end{array}$ \\
\hline エキナシア, Echinacea & $\begin{array}{l}\text { 肝毒性のある薬剤, たとえ } \\
\text { ば蛋白同化ステロイドやア } \\
\text { ミオダロン, メソトレキ } \\
\text { セート, ケトコナゾールな } \\
\text { ど }\end{array}$ & 肝障害を起こす可能性がある. & ただし，臨床的に問題になったことはない. \\
\hline $\begin{array}{l}\text { フィーバーフュー, } \\
\text { Feverfew }\end{array}$ & $\begin{array}{l}\text { ワルファリンを始めとした } \\
\text { 血栓予防薬 }\end{array}$ & 抗血小板作用が増強する可能性がある. & $\begin{array}{l}\text { フィーバーフューには血小板機能抑制作用が } \\
\text { ある. }\end{array}$ \\
\hline ニンニク, Garlic & $\begin{array}{l}\text { ワルファリンを始めとした } \\
\text { 血栓予防薬 }\end{array}$ & 抗血小板作用が増強する可能性がある. & ニンニクには血小板凝集抑制作用がある. \\
\hline ショウガ, Ginger & $\begin{array}{l}\text { ワルファリンを始めとした } \\
\text { 血栓予防薬 }\end{array}$ & 出血時間の延長. & $\begin{array}{l}\text { ショウガにはトロンボキサン合成酵素抑制作 } \\
\text { 用がある. }\end{array}$ \\
\hline \multirow[t]{3}{*}{ イチョウ, Ginkgo } & $\begin{array}{l}\text { ワルファリン, アスピリ } \\
\text { ン, NSAID など }\end{array}$ & 血小板凝集抑制作用の元進. & $\begin{array}{l}\text { ginkgolide Bは血小板活性化因子を抑制し，ア } \\
\text { ラキドン酸カスケード非依存性に血小板凝集 } \\
\text { 抑制を示す. }\end{array}$ \\
\hline & 抗痤攣剤 & $\begin{array}{l}\text { 抗㽷攣剂の効果を減弱する可能性があ } \\
\text { る. }\end{array}$ & Gikgo toxinは神経毒性を有する。 \\
\hline & サイアザイド系利尿剂 & 血圧が上昇したとの報告がある. & \\
\hline \multirow[t]{3}{*}{$\begin{array}{l}\text { チョウセンニンジン, } \\
\text { Ginseng }\end{array}$} & $\begin{array}{l}\text { ワルファリン, アスピリ } \\
\text { ン, NSAIDなど }\end{array}$ & 抗血小板作用の増強. & チョウセンニンジンには抗血小板作用がある. \\
\hline & Phenelzine & $\begin{array}{l}\text { 頭痛，振戦，躁状態などの症状をきたし } \\
\text { たとの報告がある. }\end{array}$ & $\begin{array}{l}\text { チョウセンニンジンは中枢神経刺激作用を有 } \\
\text { する. }\end{array}$ \\
\hline & コルチコステロイド & $\begin{array}{l}\text { コルチコステロイドの副作用を増強する } \\
\text { 可能性がある. }\end{array}$ & $\begin{array}{l}\text { チョウセンニンジンはコルチコステロイド様 } \\
\text { 作用を有する. }\end{array}$ \\
\hline Siberian Ginseng & ジゴキシン & $\begin{array}{l}\text { ジゴキシンアッセイに影響し, 見かけ上 } \\
\text { 上昇させる. }\end{array}$ & \\
\hline $\begin{array}{l}\text { ノコギリパルメット, } \\
\text { Saw Palmetto }\end{array}$ & $\begin{array}{l}\text { 前立腺肥大治療薬, エスト } \\
\text { ロゲン製郕, 経口避妊薬 }\end{array}$ & 相加作用を示す可能性がある. & $\begin{array}{l}\text { ノコギリパルメットはジヒドロテストステロ } \\
\text { ンのアンドロゲン受容体への結合阻害作用, } \\
\text { 5- } \alpha \text {-リダクターゼ活性阻害作用を有する. たた } \\
\text { し, 臨床的に問題になったことはない. }\end{array}$ \\
\hline \multirow[t]{4}{*}{$\begin{array}{l}\text { セント・ジョンズ・ } \\
\text { ワート, St.John's wort }\end{array}$} & $\begin{array}{l}\text { ピロキシカム, テトラサイ } \\
\text { クリン }\end{array}$ & 光過敏症が起こる可能性がある. & \\
\hline & $\begin{array}{l}\text { モノアミンオキシダーゼ } \\
\text { (MAO) 阻害薬 }\end{array}$ & 医薬品の作用増強. & $\begin{array}{l}\text { セント・ジョンズ・ワートには MAO 抑制作用 } \\
\text { がある. }\end{array}$ \\
\hline & $\begin{array}{l}\text { 選択的セロトニン受容体拮 } \\
\text { 抗薬 (SSRI) }\end{array}$ & $\begin{array}{l}\text { 七ロトニンによる症状, 頭痛, 発汗, } \\
\text { 立ちくらみ, 刺激性が起こる可能性が } \\
\text { ある. }\end{array}$ & \\
\hline & 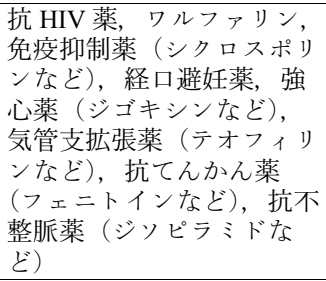 & 医薬品の作用減弱. & $\begin{array}{l}\text { セント・ジョンズ・ワートはチトクローム } \\
\text { P450 (CYP) 3A4，P4502CA9を誘導する.P-P糖 } \\
\text { 蛋白を誘導することでジゴキシン薬剤代謝 } \\
\text { に影響する. }\end{array}$ \\
\hline バレリアン, Valerian & バルビタール系薬剤 & 睡眠を延長させる. & \\
\hline カバ, Kava & $\begin{array}{l}\text { 睡眠薬, 精神安定薬, 向精 } \\
\text { 神薬 }\end{array}$ & 錐体外路症状の出る可能性がある. & $\begin{array}{l}\text { 重篤な肝機能障害が報告され，日本国内での } \\
\text { 販売は中止. }\end{array}$ \\
\hline クロレラ & ワルファリン & ワルファリンの作用を減弱する. & クロレラはビタミン K を含も. \\
\hline サイリウム, Psyllium & リチウム & リチウム濃度が低下する. & \\
\hline
\end{tabular}

文献 18) より，一部改変. 
表 5 術前に中止すべきハーブ類

\begin{tabular}{|c|c|c|c|}
\hline ハーブ名 & 主たる薬理作用 & 手術の際の注意点 & 術前のハーブ中止期間 \\
\hline エキナシア, Echinacea & 細胞性免疫活性の賦活 & $\begin{array}{l}\text { アレルギー反応, 免疫抑制剂の効 } \\
\text { 果減弱, 長期椇取による免疫能の } \\
\text { 減弱 }\end{array}$ & データ無し \\
\hline $\begin{array}{l}\text { 麻黄 (エフェドラ), } \\
\text { Ephedra }\end{array}$ & $\begin{array}{l}\text { 交感神経刺激作用による心拍数増 } \\
\text { 加, 血圧上昇 }\end{array}$ & $\begin{array}{l}\text { 頻脈及び血圧上昇による心筋梗 } \\
\text { 塞, 脳卒中の危泩, 八ロー七ン } \\
\text { による心室性不整脈, 長期摂取に } \\
\text { 伴ら内因性力テコラミンの枯渴に } \\
\text { よる循環動態の不安定化, モノア } \\
\text { ミンオキシダーゼとの併用による } \\
\text { 生命の危険性 }\end{array}$ & $\begin{array}{l}\text { 少なくとも術前 } 24 \text { 時間前からの } \\
\text { 中止 }\end{array}$ \\
\hline ニンニク, Garlic & $\begin{array}{l}\text { 血小板凝集抑制（报そらく不可逆 } \\
\text { 的，線溶允進，意義不明の降压 } \\
\text { 効果 }\end{array}$ & $\begin{array}{l}\text { 出血リスクの増加（特に血小板凝 } \\
\text { 集抑制剤との併用時） }\end{array}$ & 少なくとも術前 7 日間の中止 \\
\hline イチョウ葉, Ginkgo & 血小板活性化因子の抑制 & $\begin{array}{l}\text { 出血リスクの増加（特に血小板凝 } \\
\text { 集抑制剂との併用時） }\end{array}$ & $\begin{array}{l}\text { 少なくとも術前 } 36 \text { 時間前からの } \\
\text { 中止 }\end{array}$ \\
\hline $\begin{array}{l}\text { チョウセンニンジン, } \\
\text { Ginseng }\end{array}$ & $\begin{array}{l}\text { 血糖降下，血小板凝集抑制（おそ } \\
\text { らく不可逆的），PT-APTT 延長 } \\
\text { (動物実験)，その他種々の作用 }\end{array}$ & $\begin{array}{l}\text { 低血糖, 出血リスクの増加, ワル } \\
\text { ファリンの抗凝固作用の減弱 }\end{array}$ & 少なくとも術前 7 日間の中止 \\
\hline カバ, Kava & 鎮静, 抗不安 & $\begin{array}{l}\text { 麻酔薬の鎮静作用増強, 耽溺, 耐 } \\
\text { 性, 禁断症状 (未研究) }\end{array}$ & $\begin{array}{l}\text { 少なくとも術前 } 24 \text { 時間前からの } \\
\text { 中止 }\end{array}$ \\
\hline $\begin{array}{l}\text { セント・ジョンズ・ワー } \\
\text { ト, St.John's wort }\end{array}$ & 神経伝達物質の再取り込み抑制 & $\begin{array}{l}\text { CYP誘導作用による種々の薬剤濃 } \\
\text { 度低下 (表 } 1 \text { 参照) }\end{array}$ & 少なくとも術前 5 日間の中止 \\
\hline バレリアン, Valerian & 鎮静 & $\begin{array}{l}\text { 麻酔薬の鎮静作用増強, ベンゾジ } \\
\text { アゼピン様の禁断症状, 長期拱取 } \\
\text { による麻酔薬必要量の増加 }\end{array}$ & データ無し \\
\hline
\end{tabular}

文献 18)より引用

まずここでどのよらな目的で健康食品を利用する場合が あるのかを考光てみよう，筆者の考光る健康食品の利用 目的として以下を挙げてみた.

1）疾病の治療あるいはその補助的な手段

2) 疾病の予防

3）健康増進

4) 瘦身

5）体力増強

6）心理的な支光

7) 癒し

もちろん,これらの他にも目的があるかもしれないし， 目的が一つではなく複数にまたがっている場合もあるか もしれない。しかし，このように目的を明らかにするこ とで必要な情報が異なってくることをここでは強調した い.

上記の 1）～5）の目的の場合は，客観的な指標や目標 を設置することができるし，それらは科学的に評価する こともできる. 疾病の治療であれば, 疾病が治癒したか, 症状が改善したかを目標とすればよいし，疾病の予防で あ机ば，疾病の発症を回避することが目標となる。これ らの目的を達成するための健康食品を選択するためには 科学的なデータが必要であるし，逆にそれなくしては判
断することができない，それに比べて 6），7）を目的と して健康食品を利用する場合には，科学的なデータが必 要な場合もあるが，必ずしも必須であるとは言えない。 利用者が満足するかしないかといった主観が判断の中心 となる. したがって，1）～5）を目的とした健康食品と 6，7）を目的とした健康食品に必要な情報は異なるので ある，ただし，いずれの場合も健康食品の安全性が保証 されていなければならないことはいらまでもない，以下 の議論は主として 1）～5）などの客観的な指標が得られ る健康食品を念頭に置いたものとご理解いただきたい。

\section{8. 健康食品の類型}

\section{一健康食品により必要なエビデンスが異なる一}

健康食品の中には活とんぞ安全性に問題ないビタミン の類から医薬品並久の効果を期待するものまで様々であ る. したがって, 健康食品に一様なエビデンスを要求す ることは現実的ではない，そこで筆者は，安全性や必要 なエビデンスを考学る際に健康食品を次の 3 つの類型に 分けることを提案している13).

1）栄養補填型健康食品

2）食品成分型健康食品 
3）薬効成分型健康食品

1）栄養補填型健康食品

これは文字通り必須栄養素を補填するための健康食品 であり, ビタミン，ミネラル，食物繊維がこれにあたる. 従来よりサプリメントと呼ばれてきたものである。今で はその汇とんどが栄養補助食品の表示があり, 所要量, 過娂症となる量, 過娂症の症状などもわかっているため, 摂取の際に問題となることはない，使用する場合は，自
らの食生活と照らし合わせ足らない思われる部分を補ら とよい。ただし，利用の際には最低限の栄養学の知識を 持つべきであろう.

2）食品成分型健康食品

このタイプに含まれる健康食品の成分として，大豆に 含まれるイソフラボンや大豆ペプチド，大豆蛋白や魚に 含まれる EPA，DHA な゙が挙げられる，これらの成分 は上記の栄養補填型健康食品と違い, 人に必須の栄養素

表 6 健康食品の目的とそれに必要な情報と注意点

\begin{tabular}{|c|c|c|c|c|c|}
\hline 目 的 & 利用する前に & 特 徵 & 例 & 必要な情報 & 注意点 \\
\hline $\begin{array}{l}\text { 栄養の補助 } \\
\text { (栄養補填 } \\
\text { 型) }\end{array}$ & $\begin{array}{l}\text { 食生活を見直し, 栄養性 } \\
\text { 分の過不足を分析し, 食 } \\
\text { 生活の改善による解決を } \\
\text { 試みる. それでもなおか } \\
\text { つビタミン, ミネラルが } \\
\text { 不足する場合に, 該当す } \\
\text { るサプリメントを選択す } \\
\text { る. }\end{array}$ & $\begin{array}{l}\text { 今までの研究により } \\
\text { 様々な情報があり, 比 } \\
\text { 較的安全, 安価である. }\end{array}$ & $\begin{array}{l}\text { ビタミン, ミネ } \\
\text { ラル類 }\end{array}$ & $\begin{array}{l}\text { それぞれのビタミン・ } \\
\text { ミネラル類の特徵. 至 } \\
\text { 適用量, 欠乏症, 過剰 } \\
\text { 症などの情報. }\end{array}$ & $\begin{array}{l}\text { 健康食品は実際の食事 } \\
\text { に替わるものではない. } \\
\text { 中には過剰症の心配が } \\
\text { あり, 記載された用量 } \\
\text { を守る. }\end{array}$ \\
\hline $\begin{array}{l}\text { 疾病予防 } \\
\text { (食品成分 } \\
\text { 型) }\end{array}$ & $\begin{array}{l}\text { 利用者の疾病リスク, 疾 } \\
\text { 病に対する考方に基づ } \\
\text { そて, 目的を設定する. } \\
\text { そのための生活習慣の見 } \\
\text { 直しなど, 確実にリスク } \\
\text { を減らせる方法を考慮す } \\
\text { る. それだけでは不十分 } \\
\text { であると考えた場合に該 } \\
\text { 当するサプリメントを利 } \\
\text { 用する. }\end{array}$ & $\begin{array}{l}\text { 主として食品から有効 } \\
\text { 成分を抽出したサプリ } \\
\text { メンが該当する. 日 } \\
\text { 頃食べている食品が原 } \\
\text { 料であるため比較的安 } \\
\text { 全性は高い. 主として } \\
\text { 生活習慣病の予防に利 } \\
\text { 用されることが多く, } \\
\text { 長期にわたって利用す } \\
\text { る必要がある. あまり } \\
\text { 即効性は期待できない. }\end{array}$ & $\begin{array}{l}\text { イソフラボン } \\
\text { (大豆), EPA・ } \\
\text { DHA (魚の油), } \\
\text { リコペン (トマ } \\
\text { ト)など. }\end{array}$ & $\begin{array}{l}\text { その食品と疾病予防の } \\
\text { 関連を示したコホート } \\
\text { 研究など. できればそ } \\
\text { のサプリメントに関す } \\
\text { るランダム化比較試験 } \\
\text { のあることが望ましい. }\end{array}$ & $\begin{array}{l}\text { 食品の形でとった場合 } \\
\text { の効果が証明されてい } \\
\text { るものがあるが, 特定 } \\
\text { の成分を抽出したもの } \\
\text { に同じような作用があ } \\
\text { るかは不明. 予防効果 } \\
\text { を証明するための臨床 } \\
\text { 研究には多大な費用と } \\
\text { 時間がかかるため, 臨 } \\
\text { 床データに乏しい. 特 } \\
\text { 定の成分だけを長期間 } \\
\text { 服用した場合の安全性 } \\
\text { が確立していない. }\end{array}$ \\
\hline $\begin{array}{l}\text { 疾病治療の } \\
\text { 補助 } \\
\text { (薬効成分 } \\
\text { 型) }\end{array}$ & $\begin{array}{l}\text { 医療機関での診断治療を } \\
\text { 受けた医慮する. } \\
\text { 療機関での治療を優先す } \\
\text { る. }\end{array}$ & $\begin{array}{l}\text { 中にはランダム化比較 } \\
\text { 試験にて効果が実証さ } \\
\text { れているものや海外で } \\
\text { 医薬品となっているも } \\
\text { のもあるが, 多くは動 } \\
\text { 物実験や使用経験など } \\
\text { を元に使われている. } \\
\text { 高額なものもある. }\end{array}$ & $\begin{array}{l}\text { イチョウ葉エキ } \\
\text { ス, セント・ } \\
\text { ジョンズ・ワー } \\
\text { ト,ノコギリヤ } \\
\text { シエキス, グル } \\
\text { コサミンなど }\end{array}$ & $\begin{array}{l}\text { できれば医薬品並みの } \\
\text { ランダム化比較試験に } \\
\text { より効果や安全性が証 } \\
\text { 明されていることが必 } \\
\text { 要. }\end{array}$ & $\begin{array}{l}\text { 日本のサプリメントは } \\
\text { 商品ごとの品質のばら } \\
\text { つきが大きい. 食経験 } \\
\text { が不十分であり, 必ず } \\
\text { しも安全性が確立して } \\
\text { いない. 疾病への影響, } \\
\text { 副作用, 医薬品との相 } \\
\text { 互作用を考慮する必要 } \\
\text { がある. }\end{array}$ \\
\hline $\begin{array}{l}\text { 㾖 身 } \\
\text { (薬効成分 } \\
\text { 型) }\end{array}$ & $\begin{array}{l}\text { 減量の原則は食事・運動 } \\
\text { トのみブるでは効果が薄い. } \\
\text { 萡法であ }\end{array}$ & $\begin{array}{l}\text { ダイエット用の健康食 } \\
\text { 品には, 消化吸収を印 } \\
\text { えるもの, 満腹感を与 } \\
\text { えて食欲を低下させる } \\
\text { もの, 基礎代謝を上げ } \\
\text { エネルギー消費を増加 } \\
\text { させるもの, 脂肪合成 } \\
\text { を抑えるもの, などが } \\
\text { ある. }\end{array}$ & $\begin{array}{l}\text { キトサン, ガル } \\
\text { シニアなど }\end{array}$ & $\begin{array}{l}\text { 効果・安全性を裏付け } \\
\text { るよらなランダム化比 } \\
\text { 較試験が,必要. }\end{array}$ & $\begin{array}{l}\text { このタイプのサプリメ } \\
\text { ントの多くは効果がな } \\
\text { い. たとえ効果があっ } \\
\text { たとしても, 安全性に } \\
\text { 問題がある. 信頼に足 } \\
\text { る臨床研究が少ない. }\end{array}$ \\
\hline $\begin{array}{l}\text { 運動能力・ } \\
\text { 体力増強 } \\
\text { (薬効成分 } \\
\text { 型) }\end{array}$ & $\begin{array}{l}\text { 基本は運動であり, あく } \\
\text { までもサプリメントは補 } \\
\text { 助的なものである. プロ } \\
\text { テインは食事から撕取す } \\
\text { ることが望ましい. }\end{array}$ & $\begin{array}{l}\text { たんぱく質の補給, 筋 } \\
\text { 肉の増強作用を目的と } \\
\text { して一部で利用されて } \\
\text { いる. }\end{array}$ & $\begin{array}{l}\text { プロテイン（た } \\
\text { んぱく質), クレ } \\
\text { アチンなど }\end{array}$ & $\begin{array}{l}\text { 効果・安全性を裏付け } \\
\text { るようなランダム化比 } \\
\text { 較試験. }\end{array}$ & $\begin{array}{l}\text { プロテインは腎障害が } \\
\text { ある人には好ましくな } \\
\text { い. 専門家の指導を受 } \\
\text { ケつつ, 摂取するべき } \\
\text { である. }\end{array}$ \\
\hline
\end{tabular}

文献 14)より 
ではないこれらの成分を摂取する意味は疾病の予防や 健康増進といえる。たとえばイソフラボンは女性ホルモ ン様の作用があるとされ，更年期障害や骨粗鬆症の予防 として用いられている。（ただし，最近その効果を否定す る研究結果も出ているが.）また，EPA やDHA は抗動脈 硬化作用など多様な効果が期待されている。これらの特 徵は，長い間人類が食していた食品の中に含まれている 成分であるということだ。人類の長い食経験によりその

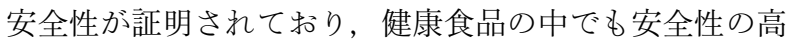
いものである. 少なくとももとになる食品の健康効果が コホート研究などで証明されていることが最低限必要で あろう。ただし，いくら食経験が長いとはいっても，特 定の成分のみを長期間摂取した場合の安全性までは保証 されていないことに留意すべきである.

3）薬効成分型健康食品

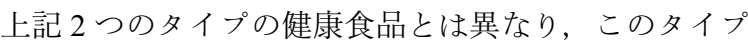
の健康食品の特徵は私たちが日常的に摂取していない成 分を含む。これらの健康食品を利用する理由は，疾病の 予防ばかりではなく, 疾病の治療, ダイエット, 体力増 強なぞ, 医薬品に近い効果を期待しているからである. たとえば痴呆に効果があるとされるイチョウ葉エキス, 関節炎に使われるグルコサミン，らつ病に用いられるセ ント・ジョンズ・ワートなぞが挙げられよう。人の食経 験が浅いといら点から，その安全性はまだ未知であると 認識して扔くべきであろら。その安全性に不安が残る以 上，それを上回る効果が要求される。.これらの健康食品 は特定の効果を期待して摂取されるべきものであるか ら，ランダム化比較試験にてその効果が評価されていな ければ摂取する意味がないとも言える。

以上を表 6 にまとめた.

\section{9. 健康食品を利用する際の 4 つの指標}

健康食品を利用し始めた人に, 「何のために健康食品を 摂取しているのですか?」と聞くと明確に答えられない 場合がしばしばある。これは，人に勧められるまま，何 となく健康食品を利用し初めてしまったからである。健 康食品を利用寸る場合，本当に効果があるのかといらこ とはもちろんのこと，その利用は投資した費用に見合っ ているのかといら問題も考光ねばならない。一般の食品 であれば，おいしいか，好きか嫌いか，価格が高いか安 いかを考光て選択寸机ばよいが，健康食品の利用の判断 はその目的が抽象的である分，判断が難しい．

そこで，筆者は健康食品を利用すべきか否かを，以下 の 4 つの指標を総合的に用いて判断することを提案して いる ${ }^{14)}$
1）対象とする疾病や健康食品に対する個人的な考光方 や価值観

2）健康食品のエビデンス（科学的根拠）

3）健康食品にかけられる費用

4）健康食品の副作用や医薬品との相互作用などの問題 点

この中で 1）と 2）を合わせたものが 3）を4）合わせ たものより，より重みがあれば健康食品を利用すると判 断すればょい，2），4）についてはすでに述べた．以下 1）３）について説明したい.

\section{0. 健康食品利用に関わる個人の価值観}

疾病に対する感じ方は人それぞれである。がんが怖い と思っている人もいるし，母親をクモ膜下出血でなくし た人はクモ膜下出血や高血圧を恐孔ているかもしれな い，また，同じ疾病を恐れていてもその程度は様々であ る。したがって，個人がその疾病をどのように考えてい るか，ぞの程度重要視しているかをまず考光る必要があ

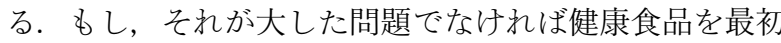
から考光る必要もないだろう。もし，がんを予防したい といら気持ちが強ければその目的を達成できる健康食品 を探すことになる，すると，それを裏付けるエビデンス があるかどらかが問題となる。 そのエビデンスの程度も， 利用者がその疾病に対してどのように考えているかによ りそのレベルが異なる。たと光ば，確実に効果のある健 康食品を利用したいと考光ればランダム化比較試験な ぞ，よりエビデンスレベルの高い健康食品を探すことに なるであろらし，万が一にも効果があればよいという考 え方に従えばエビデンスレベルは重要視されないかもし れない。

個人の価值観は要求されるエビデンスレベルに反映さ れると同時に，健康食品への投資の程度（時間・費用） にも影響する，今までは意外とこの点まで考慮されてい なかった。健康食品の摄取によりそれなりの効果を得る ためには長期にわたって利用しなければならない，疾病 の予防なぞを目的とした場合は特にそらである。した がって，それに費や寸費用も馬鹿にならない，健康食品 に費やす費用は月に数千円から数万円，時に十数万円に も及ぶ.これが数年にわたれば相当の額を健康食品に投 資することになるが，それに見合った効果が得られるか ぞらかは疑問である。あらかじめ，ぞれくらいの費用が かかるか，それだけの投資をする価值があるかどらか考 えた上で利用すべきである。 また，がんに対する健康食 品は高額なものが多く，患者の生活を圧迫したり，不必 要な時間を費やす結果となりか称ない，その健康食品の 
費用対効果を推定するためにも客観的な情報収集が必要 である。

以上から，健康食品を前にしたとき，私たちは自らの 健康や疾病に対する価值観を問われていると考えること もできる.

\section{1. 健康食品の情報源}

以上からもわかると拉り, 健康食品に関する客観的, 科学的データを収集することはきわめて重要なことであ るが，困難な作業でもある。しかし，消費者がこれらの 情報を要求しない限り，提供されないといらことも事実 である. 消費者が科学的な情報を選択の判断基準として いるといら姿勢を示すことで，企業の姿勢も変わってく るであろら。このような情勢の中で徐々に客観的情報を 提供する試みが始まっている．特にインターネットは常 に新しい情報が提供されるため有用な情報源と考兄られ る、以下に，参考となるインターネットサイトを紹介し た。

- 独立行政法人 国立健康・栄養研究所：「健康食品」の 安全性・有効性情報 http://hfnet.nih.go.jp/main.php 日本の健康食品のエビデンスの概略が分かる.

- Memorial Sloan-Kettering Cancer Center: Information Resource: About Herbs, Botanicals \& Other Products. http://www.mskcc.org/mskcc/html/11570.cfm

健康食品の解説，エビデンスの解説がある.

- Supplement Kuchikomi Ranking http://www.supplerank.com/

健康食品のエビデンスの他，医薬品との相互作用に関 する情報に詳しい，

- Consumer Lab http://www.consumerlab.com/

米国で販売されているサプリメントの成分調査を行っ ているサイト，会費を払らとサプリメントの解説も読 むことができる。

\section{2. 利用する際にどのような点に注意すればよいか？}

エビデンスはつね他人のデータでしかない，個人が 利用する場合には，その効果，安全性を利用者自ら判定 することになる．健康食品がその利用目的の主役ではあ り光ないのだから，安全性を第一と考光，効果がなかっ たり，少しでも体調が悪化したりすれば，直ちに中止す る覚悟も必要である. 健康食品利用の際の注意点を以下
に示した ${ }^{14)}$.

\section{1 購入するときは少量から}

悪質な業者は，まとめ買いをすると安くなるからと， 一度に大量に売ららとする。しかし，利用者にとってそ の効果や安全性がはっきりしない以上，少量から購入す べきである.

\section{2 常に体調の変化を監視する}

ビタミン，ミネラルなどについては，過剩症の出現す る量がわかって抢り，量を守っていれば問題となること はない，そのほかの健康食品では，下痢や吐き気などの 消化器症状や発疹なぞがみられることもあり，中には肝 障害なぞもきたす。このため，健康食品摂取後体調の変 化が見られたときには直ちに中止し，医療機関を受診す るよう指導する，業者によっては体調の悪化を好転反応 と呼び，継続利用を促す場合もあるが，決してそのよう な助言に従らべきではない，また，利用に際しては，体 調のよいときに，規定量より少な目から始めた方が無難 である。

\section{3 セルフモニタリング}

健康食品の効果を自ら判定するためには，客観的な指 標を設け，期間を区切って利用することが重要である. 効果がないにもかかわらずただいたずらに利用し続ける べきではない，指標として，糖尿病の改善を期待するな らば血糖値やへモグロビン A1c, がん治療の場合ならば, がんが縮小するかなど客観的に評価しやすいものが望ま しいが，目的によっては食欲が出る，痛みが和らぐなど の自覚症状でもかまわない，あらかじめ利用期間を決め て扣き，その指標が改善したかどらかを確認し，その後 も継続するかどうか再度その時点で判断すればよい，栄 養の補助や病気の予防など具体的な指標を設けること難 しい場合でも，期間を区切り，そのつど健康食品の必要 性を考光直した方がよい。

\section{3. 健康食品のためにこれから望まれること}

私は，これからの健康食品の有効利用に向けて，企業 と直接的な利害関係のない第三者機関による以下のよう な体制作りが必要であると考㝋ている。

\section{1 健康食品の臨床研究のための資金的サポート}

医薬品と異なり，健康食品自体で特許をとることが難 しい. しかも，臨床研究を行うには膨大な費用がかかる. しかも，すでに述べたように企業側に臨床研究へのイン 
センティブが働かない，したがって，米国におけるよう な健康食品の臨床研究に対する公的な資金援助飞考光秝 ばならない。

\section{2 健康食品の多施設研究を可能とするための企業と 医療機関との連携強化}

健康食品は医薬品に比べその効果が小さい可能性もあ り，その効果を検証するためにはサンプル数を増やす必 要がある. 多施設での臨床研究を推進するためには，健 康食品会社と医療機関との間を取り持つ機関が必要であ る.

\section{3 健康食品の臨床研究の事前登録制と研究結果の} データベース化，インターネット等での完全公開 企業側が消費者向けに直接研究データを公表すること ができないため，消費者が情報を入手することは困難で ある。したがって，企業に代わって利害関係のない第三 者機関が健康食品の情報を公開すべきである，近年よう やく国立健康栄養研究所やサプリメント・クチコミ・ラ ンキングなどが科学的データを公表するよらになってき ている．願わくば効果がなかった健康食品の情報も出し てもらいたいものである。そのためには，研究の計画段 階で登録し，その結果が良くも悪くも公表できるような システムを望みたい。

13.4 健康食品による有害事象の報告・調査の徹底，そ のデータベース化とインターネット等での公開

医薬品と異なり，健康食品による有害事象の調査・公 表は不十分である．健康食品の製造・販売会社に副作用 の収集義務などを負わせるなどして積極的に副作用情報 を収集，公開ができるようにすべきである。

\section{5 健康食品使用例の体系的な情報収集と統計解析}

健康食品の有効性を正確に判定するためにはランダム 化比較試験が望ましいが, これには費用と時間がかかる. 健康食品がこれ汪ぞ広まっている現状では，その研究結 果をいつまでも待っているわけにはいかない，そこで， 過渡的な対処として，健康食品利用例を収集・解析し， ぞのような病気に対し，ぞれくらいの確率でどの程度改 善したかについての情報を提供できるよらなシステムが 必要である。

\section{6 健康食品成分のチェック体制の整備}

日本の健康食品の成分には規格，基準がない，今後は 規格，基準の設定および第三者機関による成分チェック とその情報提供が必要である。

\section{7 医療関係者の健康食品に対する知識レベルの向上 と消費者相談機能の充実}

今までは，患者や消費者が健康食品についてアドバイ スを受けたくても，専門家がほとんどいなかった．最近， 健康食品アドバイザー制度が整備されつつあるが, 医師, 栄養士，薬剤師であっても必要最小限の健康食品に関す る知識を持つべきであろう。

\section{8 健康食品についての消費者教育}

一般の医療と異なり，健康食品は消費者独自の判断で 利用されることが多い，情報の入手方法，情報の解釈・ 判断などに関する知識が消費者にも求められている.

\section{4. おわりに}

「健康食品」に係る制度のあり方に関する検討会は次の ように「条件付き特定保健用食品（仮称）」の導入を提言 した。

「国民に対する食品機能についての正確で十分な情報 提供を確保する観点から，食品機能の表示の科学的根拠 が現行の審査基準を完全には満たしていないものであっ ても，一定の科学的根拠が存在すれば，効果の根拠が確 立されていない旨の表示をつけることを条件として、「身 体の構造／機能表示」広く許可すべきである.」15)

私には「一定の科学的根拠が存在する」ことと「効果 の根拠が確立していない」こととは矛盾しているように 思觉る。このように曖昧な健康食品など私たちには必要 ない，これまで述べてきたよらに，人が健康食品に求め るものは異なる。したがって，健康食品にどの程度の工 ビデンスがあるかを情報提供し，消費者が自ら考光選択 するシステムの方がよいのではないだろらか? 行政は筆 者の考光ていることと逆の方向に向かっているように思 える。

\section{参 考 文 献}

1) 小内亨. サプリメントの使い方一利点と弊害一. 治療. 2003; 85(11): 3021-3028

2) 個別苦情個票. OTO 番号635. http://www5.cao.go.jp/otodb/ japanese/kujyou/kobetu/OTO635.html

3）ロバート・B・チャルディニー．社会行動研究会訳．「影響 力の武器 なぜ，人は動かされるのか? 」. 誠信書房. 東 京. 1991 年.

4）朝日新聞.「健康食品「医師が推薦」と虚偽広告 本人の了 解とらず」. 1997 年 6 月 3 日付.

5) A.プラトカニス, E.アロンソン. 社会行動研究会訳.「プロ 
パガンダ」. 誠信書房. 東京. 1998 年.

6) 小内亨. インターネット上の医療・健康情報（3）ロコミ情 報としてのインターネット.あいみっく. 2001; 22(4): 24-26.

7) Vivekananthan DP, Penn MS, Sapp SK, et al. Use of antioxidant vitamins for the prevention of cardiovascular disease: meta-analysis of randomised trials. Lancet 2003; 361(9374): 2017-2023.

8) 志村二三夫. セントジョーンズワートと抗らつ作用. 薬局. 2001; 52: 1083-1091.

9) ウエンディ・ウエイガーら. 坪野吉孝訳. 解説「がんの代 替療法 有効性と安全性がわかる本」. 法研. 東京. 2004 年.

10) Takeshita A, Shinjo K, Ohnishi K, et al. Allergic Reaction Involving Liver Dysfunction and Disseminated Intravascular Coagulation Caused by a Health Food, Proporis. Internal Medicine 1995; 34: 1207-1209.

11) Adachi M, Saito H, Kobayashi H, et al. Hepatic Injury in 12 Patients Taking the Herbal Weight Loss Aids Chaso or Onshido. Ann Intern Med 2003; 139: 488-492.

12) Ruschitzka F, Meier PJ, Turina M, et al. Acute heart transplant rejection due to Saint John's wort. Lancet 2000; 355: 548-549.

13）小内亨. 鈴木信孝編著. 科学的評価に基づいた「適切な代 替医療」を選択するために．生活習慣病予防と再発防止の ために「適切な代替医療」選択のポイント，日本医療情報 出版. 東京. 2001: 29-58.

14）小内亨. サプリメントの適正使用とその指導. 薬局. 2004; 55: $1831-1838$.

15)「健康食品」に係る制度のあり方に関寸る検討会.「健康食 品」に係る今後の制度のあり方について（提言）一国民1人 1人が, 食生活の状況に応じて適切な選択ができるよう正確 な情報を広く提供する一. http://www.mhlw.go.jp/shingi/ 2004/06/s0609-1a.html

16）小内亨. 厚生労働省指定の「保健機能食品」は他の健康食 品とどう異なるのですか？治療. 2002; 84(1): 137-138.

17) 小内亨. 危ない海外のダイエット用健康食品. 肥満と糖尿 病. 2002; 1: 149-151.

18）小内亨，塚田弥生. 代替医療の日本特有の問題点. 治療. 2002; 84: 31-37.

\section{ABSTRACT \\ How to Choose Best Dietary Supplement - The Issues of Information on Dietary Supplements in Japan-}

\section{Toru ONAI}

Onai Clinic of Internal Medicine

We are exposed to advertisements of dietary supplements every day. The advertisements provide only their benefits. Therefore, consumers lack accurate information about the safety and efficacy of dietary supplements. Japanese dietary supplements have numerous problems such as lack of quality control, inadequate clinical trials, adverse events and drug interaction. It is important to know the bias of information on dietary supplements and to attempt to collect their scientific evidences and risks.

Key words: functional food, dietary supplement, herb, vitamin, mineral 